\title{
Malaría og Ísland
}

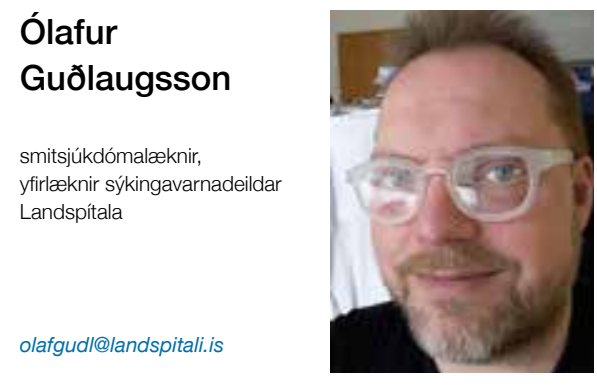

Malaría er alvarlegur smitsjúkdómur sem smitast með biti moskítóflugunnar. Prátt fyrir að góður árangur hafi náðst í baráttunni við malaríu víða, heldur hún áfram að vera stórt vandamál á heimsvísu. ${ }^{1}$ Langflest tilfelli koma upp í Afríku (88\%) og Asíu $(10 \%)$ en færri annars staðar. Töluvert er um að ferðamenn smitist af malaríu á ferðlögum á malaríusvæðum, pó ekki sé til nein tölfræði um slíkt. Samkvæmt Sóttvarnarstofnun Evrópu (ECDC) greindust rúmlega 5000 malaríutilfelli í Evrópu árið 2012 og nær öll innflutt. ${ }^{2}$

Í pessu tölublaði er samantekt um tíðni malaríu á Íslandi á tímabilinu 1998-2014. Um er að ræða staðfestar malaríugreiningar (með blóðstroki) hérlendis, en ekki tekin með tilfelli par sem Íslendingar veikjast, eru greindir og/eða meðhöndlaðir erlendis. Á tímabilinu reyndist fjöldi malaríutilfellanna vera 31, eða að meðaltali 1,8 tilfelli á ári. Í fyrri rannsókn á sama efni fyrir áratugina á undan reyndist tíðnin vera 1,5 tilfelli á ári og ekki var tölfræðilega marktækur munur par á. Í 71\% tilfella reyndist vera um Plasmodium falciparum að ræða, og flestir sjúklingarnir (90\%) frá Afríku sunnan Sahara. Tveir sjúklingar purftu á gjörgæslumeðferð að halda, par með talið meðferð í öndunarvél hjá einum og tveir purftu blóðskilun vegna bráðrar nýrnabilunar. Ekki urðu nein dauðsföll á tímabilinu. Athygli vekur að einungis tveir af pessum 30 (sem upplýsingar voru um), eða 7\%, höfðu tekið fyrirbyggjandi lyf. Eins og í mörgum erlendum rannsóknum var ástæða dvalar á malaríusvæðum í 71\% tilfella atvinna, búseta eða heimsókn til ættingja, en í 16\% tilfella var um túristaferðir að ræða. Pá var reynt að meta hvernig sala/ notkun lyfjanna hefur haldist í hendur við aukin ferðalög og var niðurstaða höfunda að mögulega væru ferðamenn síður að taka fyrirbyggjandi lyf en áđur.

Par sem ekki er hægt að bólusetja fyrir malaríu er nauðsynlegt að huga að forvörnum pegar farið er inn á svæði par sem malaría er landlæg. Nauðsynlegt er að læknar pekki mikilvægustu forvarnir gegn malaríu og geti veitt ráđgjöf um hana. Annars vegar er um að ræða almennar moskítóvarnir ${ }^{3}$ - sem par að auki verndar gegn öðrum sjúkdómum sem moskítóflugur geta borið - ljós föt, fælandi efni (DEET), síðerma/skálma fatnaður í ljósaskiptunum, flugnanet og ýmsir aðrir pættir eftir aðstæðum. Hins vegar fyrirbyggjandi lyfjameðferð ${ }^{4}$ sem líklega er mikilvægasti pátturinn. Mikið flækjustig getur verið í kringum раð аð setja upp heppilegustu fyrirbyggjandi malaríumeðferð. Раð parf að taka inn í pað nákvæma ferðaáætlun, tímalengd og aðstæður á hverjum stað, lyfjaónæmi malaríunnar á peim svæðum og heilsufari ferðalanganna. Hægt er að nálgast mjög ítarlegar upplýsingar um allt sem tengist sjúkdómsáhættu á ferðalögum og varnir gegn peim á vefnum, til dæmis á ferðavef Sóttvarnarstofnunar Bandaríkjanna CDC (nc.cdc.gov/travel/). Einnig er hægt að fá sérhæfða ráðgjöf á Íslandi hjá Ferðavernd eða Göngudeild smitsjúkdóma. En pó malarían sé mikilvæg eru fjölmargir aðrir pættir sem líka parf að huga að fyrir stórar ferðir, eins og bólusetningar og almennar upplýsingar til ferðamanna.

Hinn pátturinn sem ekki má gleyma er hve mikilvægt er að íslenskir læknar muni eftir að taka góða ferðasögu pegar sjúklingar koma inn með hita eða önnur einkenni. Malaría getur sýnt sig mánuðum eða jafnvel árum eftir dvöl á malaríusvæðum, og greinist ekki nema að henni sé leitað. Pá eru einnig margir aðrir sjúkdómar sem tengjast ferðalögum sem hafa parf í huga, og eins hverskonar ferð viðkomandi var í. Í nýlegri pýskri rannsókn ${ }^{5}$ voru skoðaðar greiningar sem tæplega 17.000 veikir ferðamenn fengu við heimkomu. Af peim reyndust 160 með malaríu en peir komu allir frá Afríku. Tíðni smitsjúkdóma var hæst í bakpokaferðalöngum frá Afríku, en reyndist lægst í ferðamönnum í viðskiptaerindum.

Malaría er alvarlegur ferðatengdur sjúkdómur sem oftast er hægt að verjast með réttum undirbúningi og aðgerðum. Íslenskir læknar purfa að vera vakandi fyrir mögulegum tækifærum til að aðstoða pá sem eru að fara að leggja lönd undir fót í að hindra að peir geti smitast af alvarlegum ferðatengdum sjúkdómum. Pá purfa læknar að vera vakandi fyrir pví hvort veikindi sjúklinga eftir heimkomu geti tengst ferðalögum sem getur pá gjörbreytt mismunagreiningum og meðferð.

\section{Heimildir}

1. WHO, World malaria report. 2015

2. Catalin Albu, S.B.a.B. Ciancio. ECDC SURVEILLANCE REPORT. Annual epidemiological report. Emerging and vector-borne diseases. 2014.

3. Nasci RS, R.A.W., Brogdon WG. Protection against Mosquitoes, Ticks, \& Other Arthropods. Yellow Book 2015. nc.cdc.gov/travel/yellowbook/2016/the-pre-travel-consultation/protection-against-mosquitoes-ticks-other-arthropods. - maí 2016

4. Arguin PM, KRT. Malaria. Yellow book 2015. nc.cdc.gov/ travel/yellowbook/2016/infectious-diseases-related-to-tra$\mathrm{vel} /$ malaria. - maí 2016.

5. Herbinger $\mathrm{KH}$, Alberer $\mathrm{M}$, Berens-Riha $\mathrm{N}$, Schunk $\mathrm{M}$ Bretzel G, von Sonnenburg F et al. Spectrum of imported infectious diseases: a comparative prevalence study of 16,817 german travelers and 977 immigrants from the tropics and subtropics. Am J Trop Med Hyg 2016; 94: 75766.

Malaria and Iceland

Olafur Gudlaugsson, M.D., M.P.H. Internal medicine/Clinical infectious diseases Director infection control, hospital epidemiologist 